\title{
Febrile reaction after hematopoietic stem cell infusion is more frequent if no steroid premedicaton is given which results in more frequent use of antibiotics in early post-transplant phase
} \author{
rano nakon transplantacije \\ Lucija Romić1 , Zinaida Perić2, ${ }^{2,}$ Lana Desnica ${ }^{3}$, Radovan Vrhovac ${ }^{2,3}$, Nadira Duraković, ${ }^{2,3}$ \\ ${ }^{1}$ Community Healthcare Centre, Zagreb, Croatia \\ 2 University of Zagreb School of Medicine Zagreb, Croatia \\ ${ }^{3}$ University Hospital Centre Zagreb, Division of Hematology, Department of Internal Medicine, Zagreb, Croatia
}

Febrilne reakcije nakon infuzije krvotvornih matičnih stanica češće su ukoliko se ne primijeni premedikacija kortikosteroidima što rezultira većom upotrebom antibiotika

\section{Keywords:}

febrile reaction

hematopoietic stem cell infusion

premedication

Ključne riječi:

febrilne reakcije

infuzije krvotvornih matičnih stanica premedikacija

Primljeno: 11-07-2020

Received: $11-07-2020$

Prihvaćeno: 16-08-2020

Accepted: $16-08-2020$

\begin{abstract}
Summary
Background: There is no consensus as to the need for steroid premedication before fresh product hematopoietic stem cell (HSC) infusion. In case of febrile reaction post-HSC infusion, on-call staff frequently prescribe antibiotics empirically. Considering the recent data on the value of microbiota and its influence on GVHD incidence, we analysed the frequency of febrile reactions and the use of antibiotic after HSC infusion in 149 consecutive patients. Methods: In the time period between 1/2018 and 10/2019, 149 patients were subject to transplantation in our institution. Per institutional standard operating procedure (SOP), all the patients received premedication before hematopoietic stem cell infusion consisting of $20 \mathrm{mg}$ chloropyramine-chlorid iv, and in case of ABO incompatible graft $1 \mathrm{mg} / \mathrm{kg}$ methylprednisolone iv. Retrospective data was collected by using patient charts. Survival probability was calculated by applying Kaplan-Meier method.

Results: Fifty-two patients received steroids, 12 patients (23\%) developing fever after graft infusion, 46 patients received no steroids, 26 of them $(57 \%)$ developed fever $(p<0.001)$. There was no difference in the number of patients having positive blood cultures. Nine (17\%) and 16 (35\%) patients received IV antibiotics in the „steroid" and no-steroid" group, respectively $(p<0.05)$. There was no difference in survival between „steroid" and "no-steroid" group.

Conclusions: Even with no difference in the frequency of febrile episodes caused by systemic infection, a significantly more patients not receiving steroid premedication develop fever and are treated with IV antibiotics, which could potentially have further implications on transplantation outcomes due to its influence on microbiota early post-transplant.
\end{abstract}

Sažetak

Uvod: Trenutno ne postoji konsenzus o potrebi primjene premedikacije kortikosteroidima prije infuzije svježih krvotvornih matičnih stanica (KMS). U slučaju febrilne reakcije nakon infuzije KMS-a, dežurno osoblje često propiše antibiotike empirijski. Uzimajući u obzir nedavne podatke o vrijednosti mikrobiote i njezinom utjecaju na incidenciju GVHD-a, analizirali smo učestalost febrilnih reakcija i uporabu antibiotika nakon infuzije KMS-a u 149 uzastopna bolesnika.

Metode: U razdoblju između 1/2018. i 10/2019. u našoj je ustanovi transplantirano ukupno 149 pacijenata. Prema institucionalnom standardnom operativnom postupku (SOP), svi su pacijenti primali premedikaciju prije infuzije krvotvornih matičnih stanica koja se sastojala od 20 mg kloropiramin-klorida iv, a u slučaju ABO inkompatibilnog presatka i 1 mg / kg metilprednizolona iv. Retrospektivno su prikupljeni podaci koristeći povijesti bolesti pacijenata. Vjerojatnost preživljavanja izračunata je Kaplan-Meierovom metodom.

Rezultati: Pedeset i dva bolesnika su primila kortikosteroide, od njih je 12 bolesnika (23\%) razvilo vrućicu nakon infuzije presatka, dok 46 bolesnika nije primilo kortikosteroide, a od njih je $26(57 \%)$ razvilo vrućicu $(p<0,001)$. Nije bilo razlike u broju bolesnika koji su imali pozitivne hemokulture. U skupini koja je primila kortikosteroide, 9 (17\%) bolesnika je liječeno iv antibioticima, dok je u skupini koja nije primala kortikosteroide, 16 (35\%) bolesnika liječeno iv antibioticima $(p<0,05)$. Nije bilo razlike u preživljenju između te dvije skupine.

Zaključci: Čak i bez razlike u učestalosti febrilnih epizoda uzrokovanih sistemskom infekcijom, znatno više pacijenata koji nisu dobili premedikaciju je razvilo vrućicu i liječilo se iv antibioticima, što bi potencijalno moglo imati daljnje implikacije na ishode transplantacije zbog utjecaja na mikrobiotu rano nakon transplantacije.
Corresponding author:
Assist. Prof. Nadira Duraković, MD, PhD

University Hospital Centre Zagreb, Division of Hematology, Department of Internal Medicine,

Kišpatićeva 12, 10000 Zagreb, Croatia;

Tel: +385 12388 370;

E-mail:nadira.durakovic@mef.hr 


\section{Introduction}

Hematopoietic stem cell transplantation (HSCT) is a curative treatment option for many hematological malignancies, as well as non-malignant disorders. The number of HSCT worldwide is increasing every year, with now alternative donor options such as haploidentical HSCT emerging, as well as emergence of new conditioning, assuring that more wide population of patients, like elderly and patients with comorbidities, can be considered for this treatment option ${ }^{[1]}$. HSC grafts required for this procedure can be obtained from umbilical cord blood, bone marrow or peripheral blood of a related or unrelated donor. Depending on their source, the grafts contain varying quantities of donor red blood cells that can potentially be bound and destroyed by conjugate blood group antibodies produced by the recipient immune system, as well as varying titres of anti- $\mathrm{ABO}$ antibodies that can lyse recipient erythrocytes after transplantation, resulting in acute haemolytic transfusion reaction. Apart from acute hemolysis upon transplantation, major complications of major ABO-incompatible transplantation include also delayed red cell engraftment and development of pure red cell aplasia (PRCA). ${ }^{[2]}$

Still, unlike solid organ transplantation, in HSCT $\mathrm{ABO}$ incompatibility is not considered a barrier for selection, such as HLA mismatch is, even though clinical outcomes of $\mathrm{ABO}$-incompatible grafts are generally considered inferior to those in $\mathrm{ABO}$-compatible $\mathrm{HSC}$, and ABO-incompatibility can have influence in engraftment, Graft-versus-host disease (GVHD) development and overall survival. ${ }^{[3]}$

$\mathrm{ABO}$ incompatibility has three features: major incompatibility, that occurs when the recipient with $\mathrm{O}$ blood group receives graft from $\mathrm{A} / \mathrm{B} / \mathrm{AB}$ donor, minor incompatibility which occurs when the donor with anti $\mathrm{A} / \mathrm{B}$ antibodies donates stem cells to a patient with $\mathrm{A} / \mathrm{B}$ or $\mathrm{AB}$ blood group and bidirectional incompatibility is defined when both donor and recipient have anti $\mathrm{ABO}$ antibodies ${ }^{[2]}$. Haemolytic reaction that occurs in $\mathrm{ABO}$ incompatible transplants can cause, among many other things, a febrile reaction. To avoid or weaken hemolytic reaction, premedication containing diphenhydramine \pm IV steroids can be given prior to stem cell infusion. Whether premedication is given or not is specific for each institution and the need for it can be determined by donor-recipient HLA disparity, source of cells (bone marrow or peripheral blood) and graft manipulation ${ }^{[4]}$. Most centres would avoid IV steroids as a premedication, at least in $\mathrm{ABO}$ compatible transplants. Also, if bone marrow is used as graft source, it contains much more erythrocytes than grafts collected from peripheral blood, even after graft manipulation and erythrocyte depletion procedure.
Given that, our institutional SOP warrants steroids to be given in case of $\mathrm{ABO}$ incompatible graft infusion. However, in case of febrile reaction, happening usually when steroids are not given as a premedication, on call staff frequently prescribes antibiotics along with antipyretics, given that these patients are often already neutropenic and systemic infection as cause of febrile reaction cannot be excluded. This results in patient being treated with broad-spectrum antibiotics from day 0 until neutrophil recovery, usually more than 14 days. After allo-HSCT, intestinal bacteria modulate risks of infection and GVHD ${ }^{[5]}$ and several studies have shown that treatment with antibiotics with increased activity against anaerobes correlates with increased graft versus host disease (GVHD) related mortality and altered intestinal microbiota in allogeneic hematopoietic stem cell transplantation (allo-HSCT) patients with fever ${ }^{[6,7]}$. Empiric antibiotics given in patients with febrile reaction, such as piperacillin-tazobactam and imipenem-cilastatin, target intestinal anaerobes that can be potent modulators of the severity of $\mathrm{GVHD}^{[8]}$. Other major problem with empiric antibiotics disturbing the normal intestinal flora is the facilitation of bacterial overgrowth with emergence of resistant microorganisms $\mathrm{s}^{[9]}$. These organisms themselves can cause serious infections, but they will also encourage the transfer of resistance factors to other bacteria. The broader spectrum of an agent, the more effect it shall have on the intestinal flora ${ }^{[9]}$.

The aim of this study was to examine how premedication practice influences the use of antibiotics early on after HSCT. For this purpose, we analysed the premedication use, frequency of febrile reactions and the use of antibiotics after HSC infusion in 149 consecutive patients being treated in the Division of Haematology of the University Hospital Centre Zagreb, Croatia in the time period from January 2018 until November 2019.

\section{Methods}

\section{Study Structure}

We conducted a single-centre retrospective study of consecutive patients who underwent allo-HSCT in our institution. The study included 149 patients transplanted in the University Hospital Centre Zagreb, Croatia between January 2018 and November 2019. Data was extracted from patient charts and electronic patient records using hospital information system.

Per institutional standard operating procedure (SOP), prior to stem cell infusion all patients received premedication consisting of $20 \mathrm{mg}$ chloropyramine-chloride intravenously (IV). In case of $\mathrm{ABO}$ incompatible graft, the patients received additional $1 \mathrm{mg} / \mathrm{kg}$ methyl- 
prednisolone IV as premedication. Temperature was measured every $2 \mathrm{~h}$ and in case of elevation in body temperature to higher than $38.1{ }^{\circ} \mathrm{C}$ blood cultures were drawn. Antibiotic therapy was introduced per physician's indication.

Fever was defined as a single axillary temperaturemeasurement $\geq 38.3{ }^{\circ} \mathrm{C}$ or at least 2 measurements of $\geq 38.0^{\circ} \mathrm{C}$, at least for $1 \mathrm{~h}$ apart at any time during $24 \mathrm{~h}$ after stem cell infusion was finished. At first recognition of fever, a minimum of two blood cultures (one through the central catheter) were drawn, a urine culture, a chest X-ray, and other tests as clinically indicated were performed. Antibiotic therapy with piperacillin/tazobactam was initiated per physician`s indication. Acetaminophen was allowed as needed to achieve symptomatic relief.

Minor ABO incompatibility was defined as a passive transfer of incompatible blood group antibodies from the donor to the recipient (e.g. from a type $\mathrm{O}$ donor to a type $A$, type $B$, or type $A B$ recipient). Major $\mathrm{ABO}$ incompatibility was defined as the presence of anti-donor blood group antibodies in recipient plasma (e.g. from a type $A$, type $A B$, or type $B$ donor to a type $\mathrm{O}$ recipient). Bi-directional $\mathrm{ABO}$ incompatibility was defined as the presence of both major and minor incompatibilities (e.g. type A donor to a type B recipient).

\section{Statistical Analysis}

Demographic, clinical and laboratory data analyzed are presented descriptively. $\chi 2$ was used for comparison of two groups, $\mathrm{p}<0.05$ was considered statistically significant. The probability of OS was estimated using the Kaplan-Meier method.

\section{Results}

\section{Patients' and transplantation characteristics}

Patients' and transplantation characteristics are described in Table 1. In the given time period, $72 \mathrm{fe}-$ male and 77 male patients with median age of 48 years (range 3-70) underwent hematopoietic stem cell transplantation. The majority of patients had AML ( $\mathrm{n}=72$, 48\%), 19 (13\%) MDS, 24 (29\%) ALL, 6 (4\%) AA, 6 (4\%) OMF, 9 (6\%) HL, 7 (5\%) NHL, 2 (1\%) CML, 2 (1\%) MM, 1 Fanconi anemia and $1 \mathrm{HLH}$. Ninety-five patients $(64 \%)$ received graft from a matched unrelated donor, 30 (20\%) from matched related donor and $24(16 \%)$ from haploidentical related donor. Most of the patients $(63 \%)$ received a reduced intensity conditioning and $37 \%$ of them received myeloablative conditioning. A total of 72 (48\%) patients were $\mathrm{ABO}$ compatible, while $22(15 \%)$ had major, 38 (26\%) minor and 17 (11\%) bi-directional ABO incompatibility.
Table 1. Patient and transplant Characteristics

TABlica 1. Karakteristike PaCijenata I transplantacije

\begin{tabular}{|c|c|}
\hline Patient and transplant characteristic & $\mathrm{N}=149$ \\
\hline Median age (range) & 48 years (range $3-70$ ) \\
\hline Sex & $\mathrm{n}(\%)$ \\
\hline Female & 72 \\
\hline Male & 77 \\
\hline \multicolumn{2}{|l|}{ Disease } \\
\hline Acute myeloid leukemia & $72(48)$ \\
\hline Myelodysplastic syndrome & $19(13)$ \\
\hline Acute lymphoblastic leukemia & $24(29)$ \\
\hline Aplastic anemia & $6(4)$ \\
\hline Chronic myelofibrosis & $6(4)$ \\
\hline Hodgkin lymphoma & $9(6)$ \\
\hline Non-Hodgkin lymphoma & $7(5)$ \\
\hline Chronic myeloid leukemia & $2(1)$ \\
\hline Multiple myeloma & $2(1)$ \\
\hline Fanconi anemia & $1(0.6)$ \\
\hline Hemophagocytic lymphohistiocytosis & $1(0.6)$ \\
\hline \multicolumn{2}{|l|}{ Conditioning intensity } \\
\hline MAC & $55(37)$ \\
\hline RIC & $94(63)$ \\
\hline \multicolumn{2}{|l|}{$\mathrm{ABO}$ incompatibility } \\
\hline no incompatibility & $72(48)$ \\
\hline major & $22(15)$ \\
\hline minor & $38(26)$ \\
\hline bi-directional & $17(11)$ \\
\hline \multicolumn{2}{|l|}{ Donor } \\
\hline matched unrelated & $95(64)$ \\
\hline matched related & $30(20)$ \\
\hline haploidentical & $24(16)$ \\
\hline Steroid premedication & $\mathrm{N}=98$ \\
\hline steroid & $52(35)$ \\
\hline no steroid & $46(30)$ \\
\hline $\begin{array}{l}\text { Patients receiving IV antibiotics prior } \\
\text { to day } 0 \text { (excluded from analysis) }\end{array}$ & $51(34.1)$ \\
\hline
\end{tabular}

MAC- myeloablative conditioning; RIC- reduced intensity conditioning

\section{Incidence of fever and subsequent IV antibiotic use in „steroid" and „no-steroid" group}

Fifty-one patients $(34.1 \%)$ received antibiotic treatment prior to day 0 and were excluded from further analysis which was subsequently done on 98 remain- 
ing patients. The total of fifty-two patients (53\%) received steroids as a premedication („steroid” group), and from that group 12 patients $(23 \%)$ developed fever after graft infusion, while in the group of $46 \mathrm{pa}-$ tients (47\%) that did not receive steroids („no-steroid” group) prior to graft infusion, 26 of them (57\%) developed fever $(p<0.001)$ (Figure 1). In the „steroid” group, $9(17 \%)$ patients had received IV antibiotics as opposed to "no-steroid" group, where 16 of them (35\%) received IV antibiotics $(\mathrm{p}<0.05)$ (Figure 2). There was no difference in the number of patients that had positive blood cultures within $24 \mathrm{~h}$ of graft infusion; in „steroid” group there were $3(6 \%)$ and in „no-steroid” group $4(7 \%)$ such patients ( $\mathrm{p}=0.27$ ) (Figure 3 ).

Analysis of overall survival showed no difference in the survival between patients receiving steroids as premedication and patients receiving no steroids, the curves are practically overlapping (Fig 2.A). No significant difference was found when we compared patients developing fever on day 0 to patients that remained afebrile, as well as when we compared patients who started with IV antibiotics on day 0 to ones that did not (Fig 2.B. and 2.C).

\section{Discussion}

The objective of this study was to assess how steroids used as part of premedication before HSC transfusion influence the appearance of febrile reactions and subsequent broad-spectrum IV antibiotic use. We have showed that avoidance of the use of steroids results in the rise of febrile reactions in recipients of HSC grafts, and increased use of broad-spectrum antibiotic. The use of broad-spectrum antibiotics was noted, even though there was no significant difference in bacteremia between groups.

The infusion of HSC grafts, particularly ABO incompatible ones, can lead to many undesired side-effects, and febrile reaction is one of them. Febrile reaction can occur as a part of acute hemolytic reaction in $\mathrm{ABO}$ incompatible graft infusion. ${ }^{[10]}$ However, febrile reaction can also occur in $\mathrm{ABO}$ compatible graft infusion, possibly as a reflection of immunological reactions similar to ones described in febrile non-hemolytic transfusion reactions, caused by pro-inflammatory cytokines or recipient antibodies encountering donor antigen in the blood product. ${ }^{[11]}$ Immunological reaction and subsequent cytokine release as a part of cy-

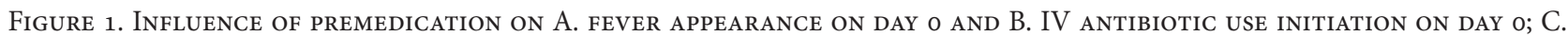
INCIDENCE OF POSITIVE BLOOD CULTURES WITHIN 24H OF GRAFT INFUSION.

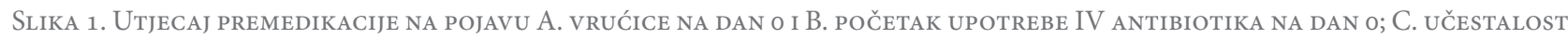
POZITIVNIH HEMOKULTURA UNUTAR 24 SATA OD INFUZIJE PRESATKA.
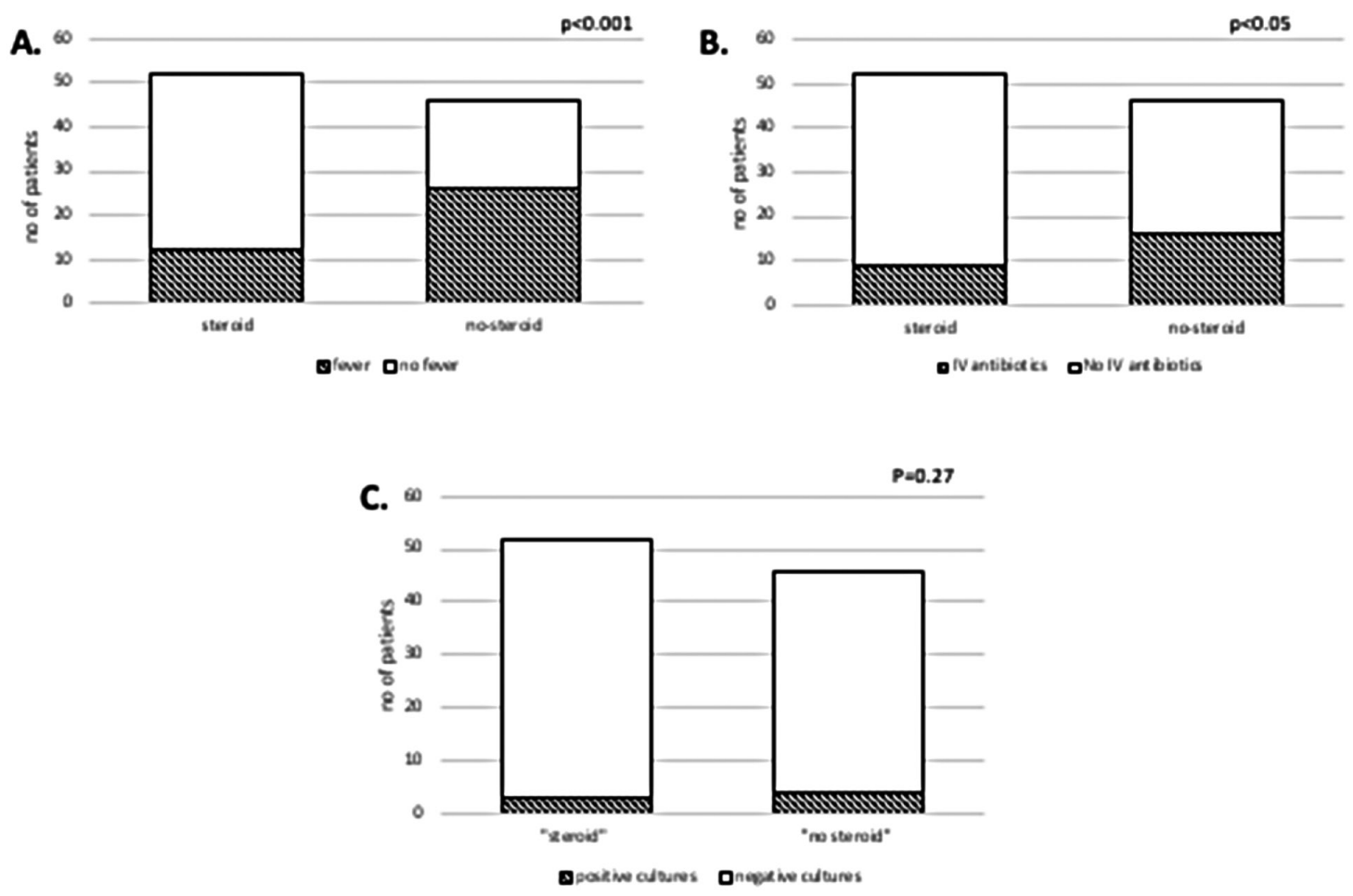
Figure 2. OVERALl SURVIVAl ACCORDING TO A. STERoID USE IN PREMEDICATION; B. FEBRILE STATE ON DAY o (P=NS); C. INITIATION OF ANTIBIOTIC THERAPY ON DAY O (P=NS)

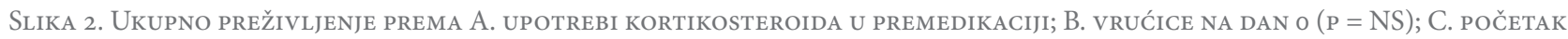
ANTIBIOTSKE TERAPIJE NULTOG DANA ( $\mathrm{P}=\mathrm{NS})$

A.

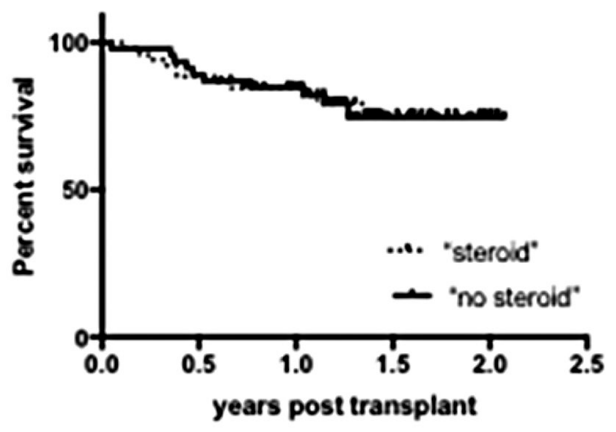

B.

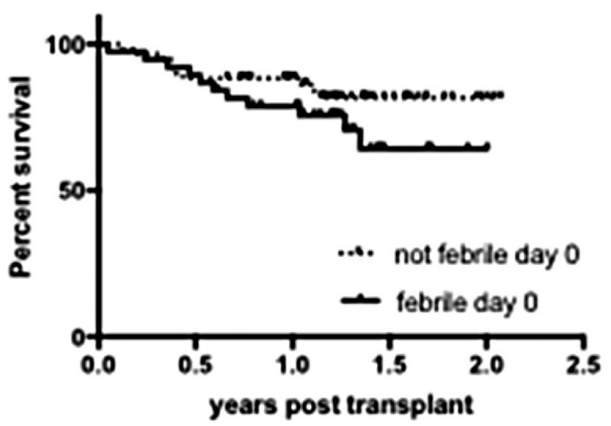

C.

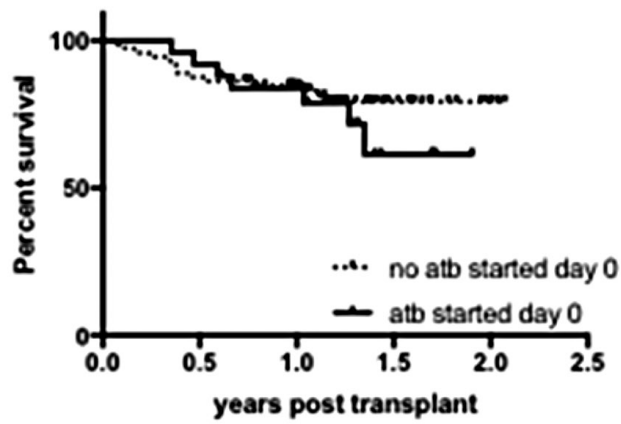

tokine release syndrome (CRS) are hypothesized to be the cause for noticed high fevers in considerable portion of patients after HSC transplantation using peripheral blood stem cells from haploidentical donors. ${ }^{[12,13]}$ It was hypothesized that the fever was likely a cytokine-mediated phenomenon associated either with initial proliferation of alloreactive $\mathrm{T}$ cells or from the actual destruction of alloreactive T cells by PTCy given per protocol on days +3 and +4 .

To avoid or weaken this haemolytic reaction, premedication such as diphenhydramine $30-50 \mathrm{mg} \mathrm{IV} /$ p.o. is given prior to stem cell infusion, and some centres, including ours, add steroids to premedication protocol in order to dampen the haemolytic reaction in $\mathrm{ABO}$ incompatible graft infusion. The occurrence of fever in these patients frequently calls for broad-spectrum antibiotic therapy initiation. The patients are usually neutropenic at that point in time and evaluating acute phase reactants such as CRP and procalcitonin is of little value as they tend to rise with any kind of immunological reaction post-transplant ${ }^{[14]}$, as well as with use of certain drugs, like anti-T cell antibody therapy, often used pre-transplant. ${ }^{[15]}$
Early use of broad-spectrum antibiotic therapy comes not without a negative effect. It particularly applies to antibiotics with increased activity against anaerobes as studies have shown that their use correlates with increased graft versus host disease (GVHD) related mortality and altered intestinal microbiota in allogeneic hematopoietic stem cell transplantation (allo-HSCT) patients with fever ${ }^{[6]}$. After allo-HSCT, intestinal bacteria modulate risks of infection and GVHD. Empiric antibiotics given in patients with febrile reaction, such as piperacillin-tazobactam and imipenem-cilastatin, target intestinal anaerobes that can be potent modulators of the severity of $\mathrm{GVHD}^{[8]}$. Other major problem with empiric antibiotics disturbing the normal intestinal flora is the facilitation of bacterial overgrowth with emergence of resistant microorganisms ${ }^{[9]}$. These organisms themselves can cause serious infections, but they will also encourage the transfer of resistance factors to other bacteria. The broader spectrum of an agent, the more effect it shall have on the intestinal flora ${ }^{[9]}$. Considering all that, and also the fact that the febrile reactions are often not caused by a systemic infection, the antibiotics use should be reduced. Howev- 
er, it is a hard decision not to start IV antibiotics, if a patient is having a fever and chills, and CRP is on the rise. We believe that this study has shown that addition of steroids to the premedication protocol can prevent the occurrence of febrile reaction and thereby decrease the use of antibiotics early on and relieve physicians in charge of making such difficult decisions. In our study we did not show survival benefit, possibly due to too low patient number. Certainly, this kind of analysis should definitely be performed in a larger patient number in order to show significant impact on survival, if any. Also, the analysis of influence of premedication practice on GVHD incidence is lacking, for which also a bigger cohort of patients would be needed in order to show significant difference due to relatively low incidence of intestinal GVHD.

\section{Conclusion}

This analysis showed that even though there is no difference in the frequency of febrile episodes caused by a systemic infection, significantly more patients that did not receive steroid as a part of premedication protocol develop fever and are treated with IV antibiotics. The use of antibiotics in early post-transplant phase without real need could potentially have further implications due to its influence on microbiota, as well as MDR strain selection. Adding steroids to premedication protocols could allow physicians to avoid early broad-spectrum antibiotics use in this patient population.

\section{REFERENCES}

${ }^{[1]}$ Passweg JR, Baldomero H, Chabannon C, et al. The EBMT activity survey on hematopoietic-cell transplantation and cellular therapy 2018: CAR-T's come into focus. Bone Marrow Transplant. 2020; 55(8):1604-1613.

${ }^{[2]}$ Vaezi M, Dameshghi DO, Souri M, Setarehdan SA, Alimoghaddam K, Ghavamzadeh A. ABO Incompatibility and Hematopoietic Stem Cell Transplantation Outcomes. Int J Hematol Oncol Stem Cell Res. 2017; 11(2): 139-147.

${ }^{[3]}$ Booth GS, Gehrie EA, Bolan CD, Savani BN. Clinical Guide to ABO-Incompatible Allogeneic Stem Cell Transplantation. Biol Blood Marrow Transplant. 2013;19 (8): 1152-1158.
${ }^{[4]}$ Scubach Slater S, Gajewski J. Transfusion medicine. In: Maziars RT, Scubach Slater S. Blood and Marrow Transplant Handbook: Comprehensive Guide for Patient Care, 2nd ed. Portland: Springer; 2015: p. 139-50

${ }^{5]}$ Peric Z, Vranjes VR, Durakovic N, et al. Gut Colonization by Multidrug-Resistant Gram-Negative Bacteria Is an Independent Risk Factor for Development of Intestinal Acute Graft-versusHost Disease. Biol Blood Marrow Transplant. 2017;23(7):1221-2.

${ }^{[6]}$ Shono Y, Docampo MD, Peled JU, et al. Increased GVHD-related mortality with broad-spectrum antibiotic use after allogeneic hematopoietic stem cell transplantation in human patients and mice. Sci Transl Med. 2016;8(339):339ra71.

${ }^{[7]}$ Koyama M, Mukhopadhyay P, Schuster IS, et al. MHC Class II Antigen Presentation by the Intestinal Epithelium Initiates Graft-versus-Host Disease and Is Influenced by the Microbiota. Immunity. 2019;51(5):885-898.

${ }^{[8]}$ Holler E, Butzhammer P, Schmid K, et al. Metagenomic analysis of the stool microbiome in patients receiving allogeneic stem cell transplantation: loss of diversity is associated with use of systemic antibiotics and more pronounced in gastrointestinal graft-versus-host disease. Biol Blood Marrow Transplant. 2014;20:640-645.

${ }^{[9]}$ Paul M, Soares-Weiser K. $\beta$ lactam monotherapy versus $\beta$ lactamaminoglycoside combination therapy for fever with neutropenia: systematic review and meta-analysis. BMJ 2003; 326:1111

${ }^{[10]}$ Davenport RD. Pathophysiology of hemolytic transfusion reactions. Semin Hematol 2005; 42:165

${ }^{[11]}$ Delaney M, Wendel S, Bercovitz RS, et al. Transfusion reactions: prevention, diagnosis, and treatment. Lancet 2016; 388: 2825-36.

${ }^{[12]}$ Arango M, Combariza JF. Fever after peripheral blood stem cell infusion in haploidentical transplantation with post-transplant cyclophosphamide. Hematol Oncol Stem Cell Ther. 2017; 10(2):79-84.

${ }^{[13]}$ O'Donnell P, Raj K, Pagliuca A. High fever occurring 4 to 5 days post-transplant of haploidentical bone marrow or peripheral blood stem cells after reduced-intensity conditioning associated with the use of post-transplant cyclophosphamide as prophylaxis for graft-versus-host disease. Biol Blood Marrow Transplant. 2015;21(1):197-8.

${ }^{[14]}$ Blijlevens NM, Donnelly JP, Meis JF, De Keizer MH, De Pauw BE. Procalcitonin does not discriminate infection from inflammation after allogeneic bone marrow transplantation. Clin Diagn Lab Immunol. 2000;7(6):889-92.

${ }^{[15]}$ Dornbusch HJ, Strenger V, Kerbl R, et al. Procalcitonin and $\mathrm{C}$-reactive protein do not discriminate between febrile reaction to anti-T-lymphocyte antibodies and Gram-negative sepsis. Bone Marrow Transplant. 2003; 32:941-5 